\title{
Peningkatan Nilai Ekonomi Kopi Menjadi Kopi Rempah Instan (KORE) Berbasis Pemberdayaan Perempuan Desa Tanah Wulan
}

\author{
Helda Wika Amini, Rizki Fitria Darmayanti, Dyah Ayu Savitri \\ Faculty of Engineering, University of Jember \\ Faculty of Agricultural Technology, University of Jember \\ heldawikaamini@gmail.com
}

\begin{abstract}
Abstrak
Kopi adalah salah satu komoditas andalan perkebunan di Indonesia. Kabupaten Bondowoso merupakan penghasil kopi dengan jumlah yang besar sehingga pada tahun 2016, Bupati Bondowoso mendeklarasikan Kabupaten ini sebagai Bondowoso Republik Kopi. Desa Tanah Wulan, Kecamatan Maesan merupakan salah satu pemasok kopi utama di Bondowoso. Desa ini memiliki potensi sumber daya manusia yang besar dengan mata pencaharian utama sebagai petani. Mayoritas perempuan berprofesi sebagai ibu rumah tangga sehingga memiliki banyak waktu luang untuk memproduksi kopi mentah menjadi kopi olahan. Namun sebagian besar hasil produksi kopi penduduk masih dijual dalam bentuk buah kopi sehingga hasil penjualan masih belum maksimal. Tingkat ekonomi dan pendidikan di desa ini masih relatif rendah dengan mayoritas keluarga prasejahtera dan penduduk belum tamat SD. Solusi yang ditawarkan pada kegiatan ini berupa pemberdayaan perempuan melalui produksi kopi rempah. Kopi rempah dibuat dengan mengolah biji kopi menjadi bubuk kopi dan menambahkan berbagai jenis rempah seperti jahe dan kapulaga untuk meningkatkan cita rasa. Kegiatan inti program ini adalah aktivasi kembali kelompok perempuan, pemberdayaan perempuan melalui produksi kopi rempah instan, dan produksi serta pemasaran untuk meningkatkan nilai jual kopi. Peningkatan nilai ekonomi kopi rempah melalui pemberdayaan petani perempuan Desa Tanah Wulan memberikan peluang yang menjanjikan. Selama pelaksanaan program, perempuan petani kopi menunjukkan antusiasme yang tinggi terhadap teknologi produksi kopi rempah dengan memberikan banyak masukan dan ide kreatif.
\end{abstract}

Kata Kunci: Kopi, Pemberdayaan, Perempuan, Rempah

\begin{abstract}
Coffee is one of the main commodities in Indonesia. Bondowoso regency produces coffee with a large quantity, thus in 2016, Regent of Bondowoso declared Bondowoso as the Republic of Coffee. Tanah Wulan Village, Maesan sub-district becoming the main coffee supplier in Bondowoso. The village has a large quantity of human resources with the main occupation as farmers. Most women taking concern in household activities. However most of the coffee produced by farmers was sold in cherry form, thus the sales results unable to meet the optimum level. The economy and education level in this village relatively low with majority of population classified as pre-prosperity family, as well as did not finished elementary school. The offered solution in this program is women empowerment through the production of spiced coffee. Spiced coffee is made by processing coffee bean into coffee powder and adding some types of spices such as ginger and cardamom for improving the taste. The main program is reactivation of women group, women empowerment through production of spiced coffee and its marketing in order to improve the sale value of coffee. The enhancement of economical value of spiced coffee through women empowerment in Tanah Wulan Village contributed to the promising opportunities. During the execution of program, the women coffee farmers was showing high
\end{abstract}


antusiams toward production technology of spiced coffee by giving many suggestions and creative ideas.

Keywords: Empowerment, Coffee, Women, Spices

\section{PENDAHULUAN}

Kopi merupakan komoditas andalan yang menyumbang bagi pendapatan nasional dan devisa negara Indonesia. Kabupaten Bondowoso merupakan salah satu sentra penghasil kopi di Jawa Timur. Badan Pusat Statistik (BPS) Provinsi Jawa Timur melaporkan produksi perkebunan kopi di Bondowoso sebesar 4288 ton pada tahun 2015 dan meningkat menjadi 8670 ton pada tahun 2016 dan 2017. Adanya peningkatan jumlah produksi tersebut menyebabkan Bondowoso saat ini dikenal sebagai "Bondowoso Republik Kopi”. Adanya deklarasi nama tersebut mempengaruhi pamor Bondowoso sebagai primadona komoditas kopi Indonesia.

Desa Tanah Wulan merupakan salah satu pemasok kopi di Kabupaten Bondowoso. Desa ini merupakan dataran tinggi yang terdiri atas pemukiman penduduk, sawah, ladang, gunung, dan hutan yang sebagian telah difungsikan sebagai daerah perkebunan kopi. Data Potensi Desa Tanah Wulan tahun 2015 menyebutkan bahwa luas perkebunan kopi di Desa Tanah Wulan mencapai 159 ha dengan hasil produksi 4,5 ton/ha. Pembukaan lahan baru menyebabkan adanya peningkatan luas tanah perkebunan kopi per tahun, sehingga terjadi peningkatan jumlah produksi kopi dari tahun ke tahun di Desa Tanah Wulan. Sebanyak 1.133 petani memiliki kepemilikan atas perkebunan kopi di Desa Tanah Wulan.

Total penduduk Desa Tanah Wulan pada tahun 2015 adalah 4.495 orang dengan rincian 2266 orang laki-laki dan 2227 orang perempuan, sehingga potensi sumber daya manusia (SDM) di Desa Tanah Wulan cukup menjanjikan. Tujuh puluh persen mata pencaharian penduduk Desa Tanah Wulan adalah petani, sedangkan penduduk lainnya berprofesi sebagai buruh tani, peternak, dan sebagainya. Sebagian besar pekerjaan dikerjakan oleh laki-laki (78\%), sedangkan sebagian besar perempuan menjadi ibu rumah tangga. Adanya potensi SDM tersebut belum mampu mewadahi aktivitas pemberdayaan masyarakat, khususnya perempuan di Desa Tanah Wulan secara maksimal. Sejak tahun 2017 lalu, Kopwan (Koperasi Wanita) dan kelompok muslimat yang memiliki program pemberdayaan perempuan masih dalam kondisi vakum.

Jika ditinjau dari aspek pendidikan, pendidikan mayoritas penduduk Desa Tanah Wulan tergolong masih rendah. Jumlah penduduk yang buta huruf mencapai 167 orang. Untuk generasi muda, bahkan penduduk yang tidak tamat SD mencapai 354 orang. Penduduk Desa Tanah Wulan didomisili tamatan SD. Sedangkan menurut data yang ada hingga tahun 2015, jumlah penduduk yang dapat mengenyam dan lulus pendidikan di perguruan tinggi hanya berjumlah 31 orang.

Pemberdayaan perempuan merupakan kegiatan mendayagunakan segala potensi, kemampuan dan keahlian perempuan guna meningkatkan kualitas diri dari masingmasing individu tersebut. Kegiatan pemberdayaan perempuan tidak lepas dari adanya latar belakang bahwa perempuan (atau ibu) merupakan manajer terbaik keluarga 
sehingga tingkat kesejahteraan keluarga bagaimanapun ditentukan oleh keahlian manajerial perempuan. Maka dari itu seringkali perempuan juga membantu roda perekonomian keluarga dengan melakukan pekerjaan sampingan, terutama pekerjaan yang bisa dikerjakan di rumah namun memberikan penghasilan yang cukup memadai.

Masalah yang menjadi prioritas dalam program ini adalah (1) tingkat perekonomian dan kesejahteraan penduduk yang masih rendah, (2) proses pengolahan kopi yang masih minim untuk peningkatan nilai jual kopi, dan (3) program pemberdayaan perempuan yang masih vakum dan minim. Diharapkan setelah pelaksanaan program ini akan terjadi peningkatan pada beberapa parameter yang dapat diamati atau dirasakan oleh anggota kelompok perempuan, antara lain (1) pengaktifkan kelompok dengan kegiatan bermanfaat, (2) peningkatan kehidupan ekonomi dengan memanfaatkan waktu luang perempuan di Desa Tanah Wulan, (3) Pengetahuan yang memadai dan berkembang untuk produksi kopi rempah beserta manajemennya, (4) Pengetahuan yang dapat meningkatkan kualitas perempuan dalam mengelola kehidupan sehari-hari, (5) Peningkatan nilai kopi melalui produk turunan dan fermentasi, (6) Peningkatan motivasi untuk produksi dengan adanya pasar yang terus dikembangkan dan (7) Adanya produk khas daerah yang menjadi awal dari pengembangan potensi lainnya dari desa.

Pada tahun 2015, total penduduk Desa Tanah Wulan adalah 4.495 orang dengan rincian 2266 orang laki-laki dan 2227 orang perempuan. Penduduk Desa Tanah Wulan, Kecamatan Maesan, Kabupaten Bondowoso sebagian besar berprofesi sebagai petani kopi (70\%), dimana Sebagian besar pekerjaan dikerjakan oleh laki-laki (78\%), sedangkan sebagian besar perempuan menjadi ibu rumah tangga. Meskipun Desa Tanah Wulan menjadi lumbung kopi di Kabupaten Bondowoso, kesejahteraan penduduk relatif masih rendah.

Tingkat kesejahteraan penduduk dikategorikan ke dalam beberapa klasifikasi antara lain keluarga prasejahtera (sangat miskin), keluarga sejahtera l (miskin), keluraga sejahtera 2 (keluarga yang dapat memenuhi semua kebutuhan dasar, kebutuhan sosial psikologis,namun belum memenuhi kebutuhan perkembanganya), keluarga sejahtera 3 (keluarga yang dapat memenuhi semua kebutuhan dasar, kebutuhan sosial psikologis, dan perkembangan keluarganya), dan keluarga sejahtera 3 plus (keluarga mapan). Jumlah keluarga prasejahtera sebanyak 709 keluarga. Adapun secara berturut-turut jumlah keluarga sejahtera 1, keluarga sejahtera 2, keluarga sejahtera 3, dan keluarga sejahtera 3 plus adalah 442, 394, 278, dan 37 keluarga. Data tersebut membuktikan bahwa terdapat lebih banyak keluarga yang hidup dibawah garis kemiskinan dibandingkan keluarga yang mapan dalam segi ekonomi.

\section{PELAKSANAAN DAN HASIL KEGIATAN}

Berdasarkan hasil wawancara dengan penduduk Desa Tanah Wulan, cara penjualan kopi hasil produksi di lahan perkebunan penduduk dibagi menjadi enam cara yaitu: (1) Penjualan pada saat kopi masih berbunga; (2) Penjualan pada saat buah kopi siap 
panen namun masih berada dibatangnya; (3) Penjualan buah basah kopi setelah dipanen; (4) Penjualan buah kopi kering; (5) Penjualan biji kopi; dan (6) Penjualan bubuk kopi. Pada sistem penjualan tersebut, khususnya sistem 1-4, petani mendapatkan untung yang lebih sedikit (kopi dijual dengan harga yang lebih murah) dibandingkan sistem 5-6 karena kopi tidak diolah atau tidak dibuat menjadi produk turunan yang memilki nilai jual/ekonomi yang lebih tinggi. Sebagian besar petani kopi di Desa Tanah Wulan menjual kopi dengan sistem 3-4. Sampai saat ini, diantara 1133 orang petani kopi, hanya satu orang yang menjual kopi dalam bentuk bubuk.

Penjualan kopi tanpa pengolahan lebih lanjut sudah menjadi kebiasaan masyarakat di Desa Tanah Wulan. Terlebih sebagian besar penduduk belum mengetahui proses pengolahan kopi lanjutan yang berpotensi menciptakan pendapatan yang lebih besar dibanding kopi tanpa pengolahan lanjutan. Pada program pengabdian ini, perempuan petani di Desa Tanah Wulan mempelajari bagaimana proses pengolahan kopi lanjutan dengan penambahan berbagai jenis rempah khas Indonesia. Adanya penambahan rempah memberikan nilai plus antara lain: (1) sentuhan cita rasa khas rempah-rempah Indonesia, 2) memberi manfaat kesehatan, terlebih rempah-rempah bersifat sebagai antioksidan yang baik dikonsumsi untuk melawan radikal bebas, 3) meningkatkan daya saing produk kopi bagi konsumen. Secara umum terdapat tiga hal yang perlu dilakukan untuk mengatasi kendala rendahnya nilai jual kopi di Desa Tanah Wulan, antara lain: Proses Pengolahan Kopi Rempah (KORE) Instan, Analisis Finansial Produk Kopi Rempah (KORE) Instan, dan Prospek Perkembangan Kopi Rempah (KORE) Instan.

\section{A. Proses Pengolahan Kopi Rempah (KORE) Instan}

Bahan baku KORE merupakan biji kopi mentah yang diproduksi oleh penduduk Desa Tanah Wulan, Kecamatan Maesan, Kabupaten Bondowoso. Kemudian biji kopi mentah disangrai dan digiling. Setelah itu dilakukan formulasi kopi rempah dengan pembuatan dua varian produk, yakni kopi jahe dan kopi jahe kapulaga. Proses pembuatan kore disajikan pada bagan berikut ini.

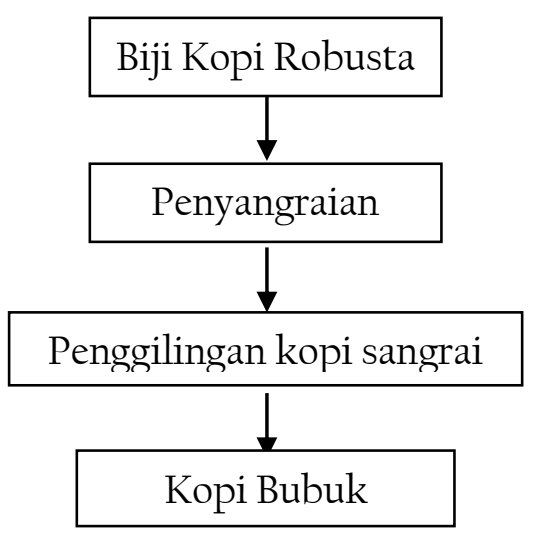

Bagan 1. Pembuatan Kopi Bubuk 


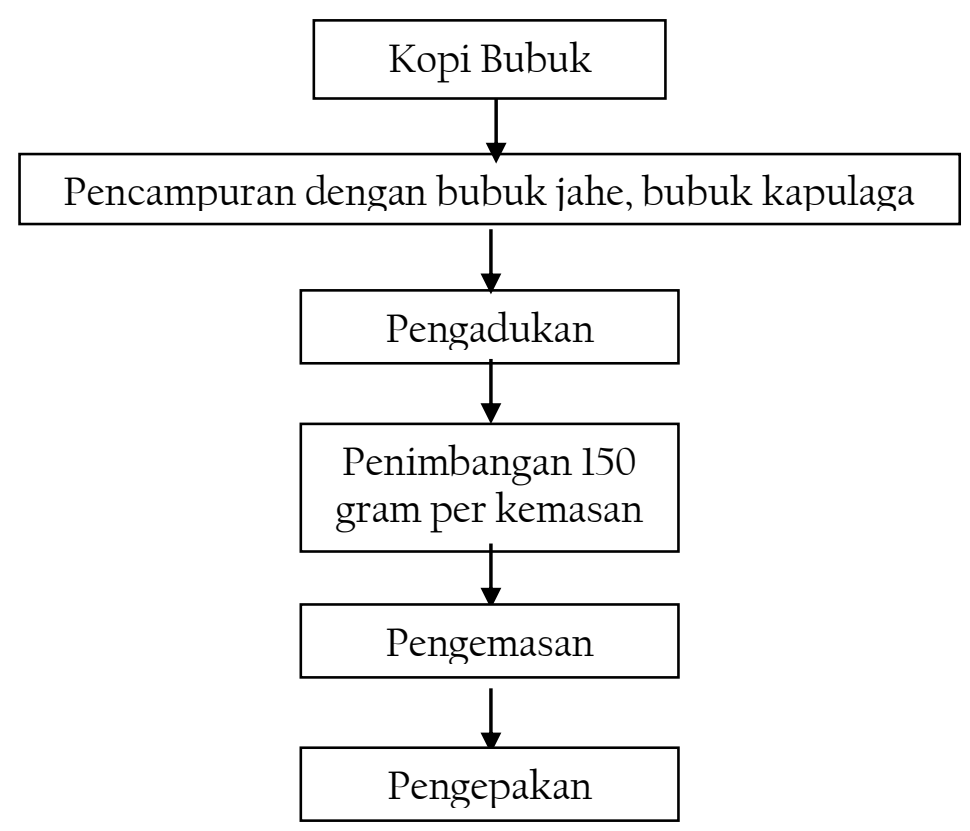

Bagan 2. Proses Pembuatan Kore

B. Analisis Finansial Produk Kopi Rempah (KORE) Instan

Pada analisis studi kelayakan, diperoleh perbandingan antara pendapatan, pengeluaran, dan keuntungan bersih dengan factor diskon sebesar 14\%. Kemudian, dapat diperoleh perhitungan Net Present Value (NPV) yang mengalami penurunan dari tahun kedua hingga kelima. NPV memiliki komponen penyusun yaitu Present Value Benefit (PVB) dan Present Value Cost (PVC). Discount factor merupakan komponen yang menentukan besarnya NPV per tahun. Nilai discount factor disesuaikan dengan MARR yang ditetapkan oleh bank sentral. Semakin besar nilai MARR maka nilai discount factor semakin besar pula. Semakin besar nilai PV(C) maka akan semakin kecil nilai NPV. Total NPV dari tahun ke 0 hingga tahun ke 5 sebesar Rp 62.304.052,7.

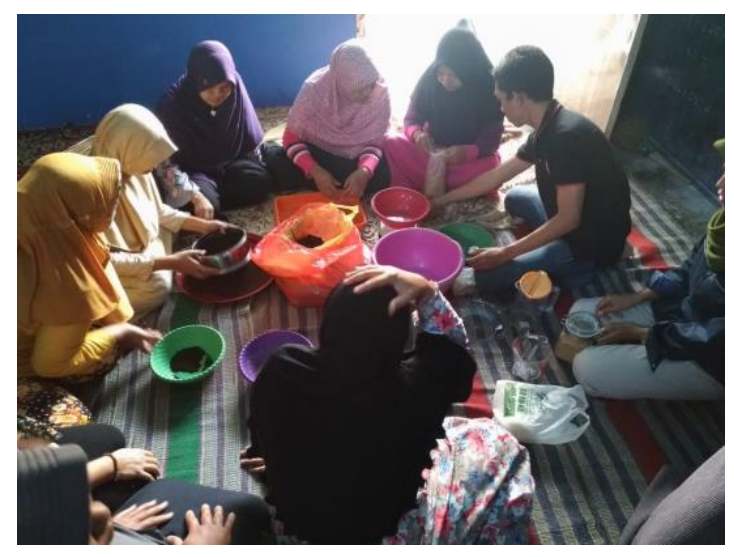

Gambar 1. Pembuatan KORE

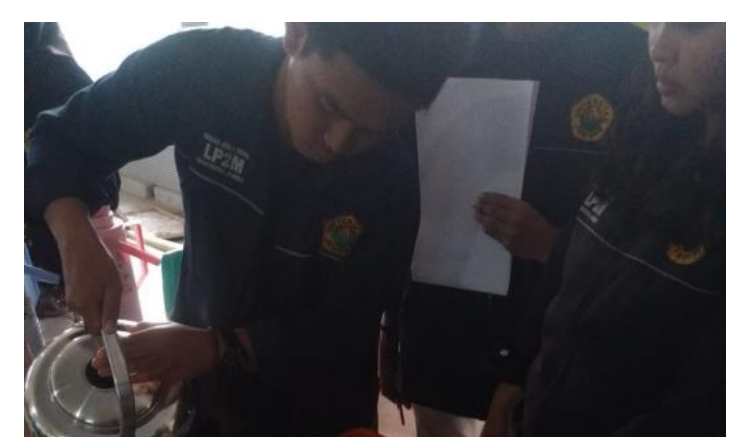


Gambar 2. Cup Test KORE

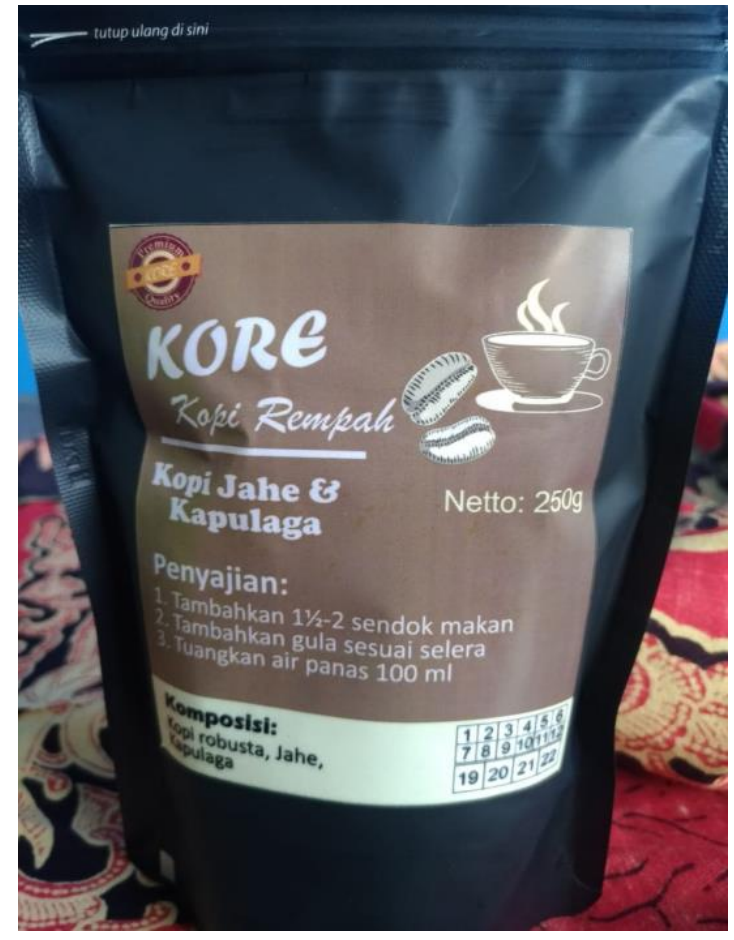

Gambar 3. Produk KORE

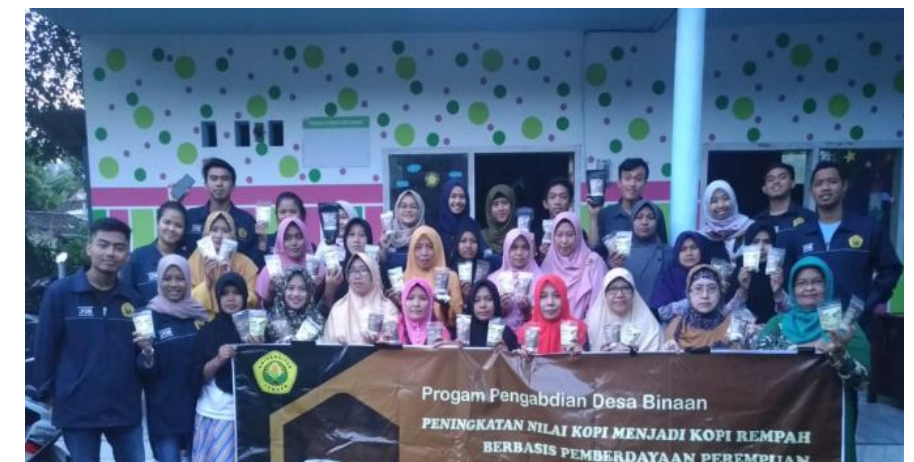




\section{Gambar 4. Foto Bersama Peserta}

Adanya biaya variabel yang mengalami kenaikan dari tahun ke dua menyebabkan perbedaan titik impas produksi per tahun berbeda-beda kemudian diperoleh nilai Break Even Point (BEP) rata-rata sebesar 37308 unit. Namun perubahan biaya variabel per tahun tidak berpengaruh besar terhadap titik impas karena perbedaannya sangat sedikit per tahun.

BEP diperoleh pada nilai 37308 artinya pada produksi KORE sebesar 37308 unit diperoleh pengembalian modal untuk biaya produksi. Diperoleh titik impas pada jumlah produksi tersebut. Produksi sebanyak 37308 unit tersebut merupakan jumlah produksi minimal yang menjadi acuan produksi supaya diperoleh titik impas. Produksi total diharapkan sebesar 37308 unit per tahun, sehingga dengan BEP sebesar itu menyebabkan usaha ini cukup menjanjikan sebab relatif cepat mendapatkan keuntungan dengan penghasilan yang cukup besar sehingga usaha layak dijalankan.

Waktu yang diperlukan supaya modal yang dikeluarkan cepat kembali adalah saat bisnis ini berjalan 0.68 tahun. Waktu pengembalian modal ini dinilai cepat sebab umur ekonomis usaha yang diperkirakan selama 5 tahun sedangkan modal dapat kembali kurang lebih setelah 8 bulan.

Pendapatan bersih yang diperoleh dari hasil penjualan selama 5 tahun adalah Rp 94.097.500. Jadi usaha KORE ini memilliki keuntungan bersih Rp 94.097.500 setelah usaha berjalan selama 5 tahun. Usaha ini memiliki NPV lebih besar dari 0 sehingga usaha ini dikatakan layak untuk dijalankan. Selain itu usaha ini juga menguntungkan secara finansial.

Dari usaha ini diperoleh IRR sebesar 210\%, suatu investasi dikatakan layak jika IRR lebih besar dari MARR. Nilai tingkat suku bunga disaat IRR sama dengan 0 berarti usaha tersebut tidak untung dan tidak rugi. Nilai MARR pada investasi ini adalah 14\%, sedangkan nilai IRR lebih besar yaitu sebesar $210 \%$ sehingga usaha ini dikatakan layak dijalankan. Menginvestasikan modal untuk usaha ini lebih menguntungkan daripada nilai deposito bank asalkan usaha ini dikelola dengan baik.

Pada produk KORE, dengan harga jual Rp 29.000 per kemasan 150 gram diperoleh B/C Ratio 1.05 yang berarti usaha ini layak dijalankan sebab nilai B/C Ratio >l. 
Pada B/C Ratio 1.05, berarti usaha KORE memberikan keuntungan bersih sebesar 1.05 kali dari total biaya yang dikeluarkan. Dari keseluruhan analisis yang telah dilakukan dapat disimpulkan bahwa usaha KORE ini layak dijalankan karena relatif cepat untuk mendapatkan keuntungan yang besar, waktu yang diperlukan untuk pengembalian modal hanya 8 bulan, NPV > 0 yaitu Rp 62.304.053, IRR lebih besar dari MARR yang ditetapkan yaitu 210\% untuk nilai IRR dan 14\% untuk nilai MARR dan B/C Ratio >1 yaitu sebesar 1,05.

\section{Prospek Perkembangan Kopi Rempah (KORE) Instan}

Produk berbasis kopi umumnya dijual dalam bentuk biji tersangrai, kopi bubuk hingga minuman kopi dalam kemasan. Namun olahan kopi yang diformulasikan dengan rempah khas Indonesia masih belum familiar di kalangan masyarakat. Penggunaan rempah-rempah dapat meningkatkan khasiat dan manfaat kopi disamping memberikan citarasa dan aroma yang khas pada produk minuman.

Jahe merah (Zingiber officinale Roscoe) yaitu gingerol, shogaol dan zingerone diketahui mempunyai efek farmakologi seperti antioksidan, antiinflammasi, analgesik dan antikarsinogenik (Yessi dkk., 2017). Masyarakat Indonesia terbiasa memanfaatkan rimpang jahe sebagai tanaman herbal untuk mengurangi rasa sakit dan radang, melawan sel kanker, anti muntah, mengobati gangguan lambung, dan lain-lain (Sadikim dkk., 2018). Kapulaga mengandung saponin, flavonoid, polifenol dan minyak atsiri. Biji tanaman kapulaga mengandung minyak atsiri, dimana dalam minyak atsirinya terdiri atas senyawa alfa bornel dan beta kamfer (Utami dkk, 2012). Adapun kapulaga memiliki khasiat melegakan tenggorokan, menghilangkan bau mulut, mengobati perut kembung dan radang tenggorokan (Sukandar dkk, 2015).

Kopi rempah instan memiliki prospek usaha yang menjanjikan, walau masih perlu promosi dan sosialisasi yang massif untuk memasarkan produk Kope rempah instan ini. Tabel berikut menyajikan secara ringkas analisis SWOT (Strength, Weakness, Opportunity, Threat) produk Kopi Rempah.

Tabel 1. Analisis SWOT Produk Kopi Rempah Instan

\begin{tabular}{|c|c|c|}
\hline SWOT Matrix & \begin{tabular}{|l}
\multicolumn{1}{c}{ Strength-S } \\
1. \\
Citarasa produk yang \\
khas perpaduan kopi \\
dan rempah-rempah \\
2. \\
Kultur kerja yang baik \\
(sumber daya, \\
manajemen usaha)
\end{tabular} & 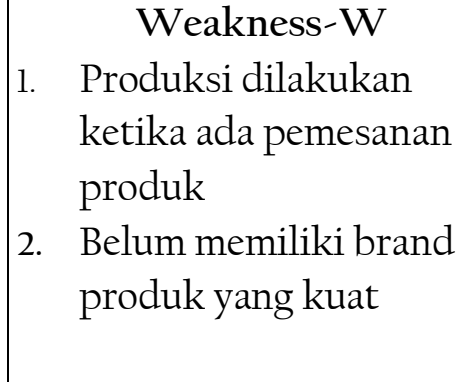 \\
\hline $\begin{array}{l}\text { Opportunities-O } \\
\text { 1. Ketersediaan bahan } \\
\text { baku yang melimpah }\end{array}$ & \begin{tabular}{ll}
$\quad$ & \multicolumn{1}{c}{ Strategi S-O } \\
1. & Meningkatkan \\
penjualan kopi rempah
\end{tabular} & $\begin{array}{c}\text { Strategi W-O } \\
\text { 1. } \begin{array}{l}\text { Produksi dilakukan } \\
\text { secara rutin dengan }\end{array}\end{array}$ \\
\hline
\end{tabular}




\begin{tabular}{|c|c|c|c|c|}
\hline 3. & $\begin{array}{l}\text { Pasar produk minuman } \\
\text { meningkat } \\
\text { Adanya pemasaran } \\
\text { sistem online yang dapat } \\
\text { memperluas jangkauan } \\
\text { kepada konsumen }\end{array}$ & $\begin{array}{l}\text { 2. Meningkatkan strategi } \\
\text { pemasaran secara offline } \\
\text { dan online }\end{array}$ & 2 & $\begin{array}{l}\text { kapasitas yang } \\
\text { disesuaikan dengan } \\
\text { permintaan pasar } \\
\text { terkini } \\
\text { Menjalin kerjasama } \\
\text { dalam hal pemasaran } \\
\text { dengan outlet oleh-oleh } \\
\text { khas daerah Bondowoso }\end{array}$ \\
\hline $\begin{array}{l}2 \\
3 .\end{array}$ & \begin{tabular}{l}
\multicolumn{1}{c}{ Threats-T } \\
Teknologi produksi \\
yang masih berskala \\
rumah tangga \\
Perang harga produk \\
Produk belum memiliki \\
image yang kental di \\
kalangan masyarakat
\end{tabular} & 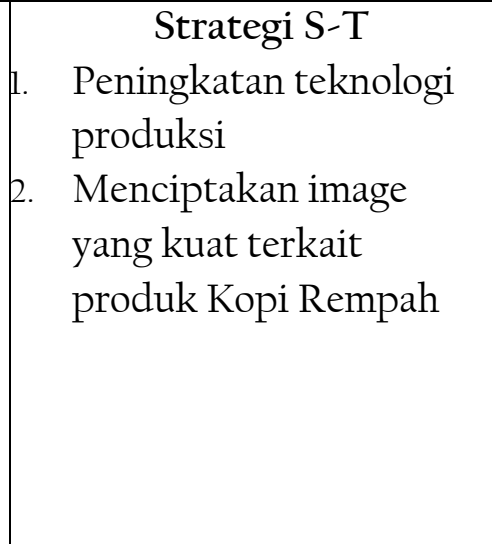 & 1. & \begin{tabular}{l}
\multicolumn{1}{c}{ Strategi W-T } \\
Produksi dilakukan \\
secara rutin dengan \\
kapasitas yang \\
disesuaikan dengan \\
permintaan pasar terkini \\
Menjalin kerjasama \\
dalam hal pemasaran \\
dengan outlet oleh-oleh \\
khas daerah Bondowoso
\end{tabular} \\
\hline
\end{tabular}

Pemberdayaan perempuan merupakan suatu usaha meningkatkan kemampuan perempuan untuk mengembangkan dirinya baik dalam hal kapasitas dan keterampilan guna memperoleh akses dan penguasaan atas posisi pengambil keputusan, sumber dan struktur atau jalur yang menunjang (Hasanah, 2013). Pemberdayaan perempuan dapat dilakukan melalui strategi penguatan, antara lain penguatan akses, pelatihan dan pendampingan. Penguatan adalah segala upaya untuk mendukung penguasaaan pengetahuan dan kemampuan perempuan untuk memecahkan masalah serta mencukupi keperluan-keperluannya. Pemberdayaan haruslah memotivasi dan menyokong perempuan untuk mendayagunakan kemampuan dan kepercayaan diri dalam rangka menunjang kemandirian perempuan (Tjiptaningsih, 2017).

Petani perempuan di Desa Tanah Wulan belum mengetahui bagaimana pengolahan kopi pada tingkat lanjutan, sehingga selama ini kopi produksi Desa Tanah Wulan memiliki nilai jual yang relatif rendah. Kopi umumnya dijual ketika masih berada di pohon atau dalam kondisi mentah. Padahal adanya perlakuan lanjutan seperti teknik penyangraian dan grinding yang tepat dan disertai dengan implementasi teknik seduhan yang tepat dapat menghasilkan citarasa dan aroma secangkir kopi yang nikmat.

Proses penyangraian biji kopi dilakukan pada suhu tinggi $\left(160-250^{\circ} \mathrm{C}\right)$. Proses ini merombak komposisi kimia biji kopi seperti karbohidrat dan asam amino yang berperan penting dalam reaksi Maillard dan pembentukan cita rasa kopi. Selama proses penyangraian terjadi transformasi senyawa volatil kopi yang menghasilkan hampir 1000 komponen aroma, sehingga proses penyangraian yang tepat diperlukan untuk 
memperoleh kopi dengan cita rasa premium. Selain itu terbentuk pula senyawa polimer seperti melanoidin yang mempunyai antioksidan kuat (Fadri dkk., 2019).

Setelah disangrai, biji kopi digiling menggunakan alat penggiling kopi, diseduh dengan air panas sehingga diperoleh cita rasa khas kopi. Penggilingan merupakan proses pengecilan ukuran yang diperlukan untuk mengendalikan ekstraksi dan disperse senyawa kimia didalam seduhan kopi. Penggilingan merupakan perlakuan yang memecah kopi sangrai menjadi partikel maupun fragmen yang lebih kecil. Hal ini diperlukan untuk pembebasan karbon dioksida, pengurangan jarak difusi untuk senyawa larut during ekstraksi dan untuk memperbaiki transfer senyawa koloid menuju fase cair (Cordoba et al, 2019).

Pada 2016 total produksi kopi Indonesia adalah 663.871 ton, sedangkan total ekspor kopi Indonesia adalah 414.650 ton (BPS, 2017). Hal ini memberikan informasi bahwa selama tahun 2016, sebanyak 62,5\% total produksi biji kopi Indonesia diperuntukkan untuk konsumsi luar negeri. Adapun harga jual kopi mengikuti perkembangan pasar, baik dalam maupun luar negeri.

Sebelum adanya kegiatan sosialisasi tentang peran perempuan dalam meningkatkan perekonomian keluarga petani kopi, para peserta belum sadar dengan potensi sumber daya alam dan sumber daya manusia di Desa Tanah Wulan. Adanya kegiatan ini membuka wawasan peserta sosialisasi, dimana perempuan juga memiliki kapabilitas untuk menjadi inovator dan penggerak masyarakat guna menghasilkan lingkungan yang dinamis dan kooperatif terhadap industri pertanian Indonesia bahkan dunia. Hal ini ditunjukkan dengan keikutsertaan peserta dalam rutinitas kegiatan produksi KORE untuk diperjual-belikan. Walau masih dalam tahap merintis, pemasaran produk KORE telah dilaksanakan secara rutin dalam skala produksi yang relatif masih kecil 100-600 bungkus kopi per produksi. Hasil pemasaran produk KORE tersebut memberikan tambahan income bagi petani perempuan yakni berkisar antara Rp 1.022.300 hingga Rp 6.133.800.

Desa Tanah Wulan berada di wilayah dataran tinggi dengan ketersediaan kendaraan umum yang terbatas sehingga akses penduduk menuju perkotaan dan sebaliknya relatif kurang mudah. Hal ini dapat diatasi salah satunya melalui strategi pemasaran produk secara online sehingga lebih memudahkan transaksi jual-beli antar produsen dan konsumen. Selain itu, produk KORE juga dapat dititipkan ke toko pusat oleh-oleh khas Bondowoso yang terletak di pusat kota atau strategis dengan lokasi konsumen.

\section{KESIMPULAN}

Perempuan memiliki potensi yang besar untuk memberdayakan komunitasnya. Peranan perempuan di Desa Tanah Wulan utamanya dilakukan melalui pengolahan biji kopi secara lanjut sehingga dapat meningkatkan nilai jual produk. Produk kopi menghasilkan keuntungan berlipat dengan pengolahan lebih lanjut, misalnya dalam bentuk Kopi Rempah (KORE). Selain itu usaha KORE akan meningkatkan pendapatan rumah tangga, khususnya perempuan. Perempuan menjadi pelatih bagi perempuan lain yang tertarik untuk mengembangkan usaha KORE di desa. Program pemberdayaan 
yang sempat vakum, dihidupkan kembali serta perempuan lebih mandiri secara finansial. Usaha KORE ini memiliki keunggulan antara lain ketersediaan bahan baku yang melimpah, citarasa produk yang khas perpaduan kopi dan rempah-rempah, kultur kerja yang baik (sumber daya, manajemen usaha), pasar produk minuman meningkat serta adanya pemasaran sistem online yang dapat memperluas jangkauan kepada konsumen.

\section{DAFTAR PUSTAKA}

BPS. 2017. Produksi Tanaman Perkebunan Menurut Propinsi dan Jenis Tanaman, Indonesia (000), 2008-2011. https:/www.bps.go.id/dynamictable/2017/03/02/1232/produksi-tanamanperkebunan-menurut-propinsi-dan-jenis-tanaman-indonesia-000-ton-20082011.html, Diakses 7 Maret 2019.

BPS, 2017. Statistik Kopi Indonesia 2017. Jakarta: Badan Pusat Statistik.

Cordoba, N., Pataquiva, L., Osorio, C., Moreno, F.L.M., Ruiz, R.Y. 2019.Effect of Grinding, Extraction Time and Type of Coffee on The Physicochemical and Flavour Characteristics of Cold Brew Coffee. Scientific Reports, 9:8440.

Fadri, R.A., Sayuti, K., Nazir, N., Suliansyah, I. 2019. Review Proses Penyangraian Kopi dan Terbentuknya Akrilamida yang Berhubungan dengan Kesehatan. Journal of Applied Agricultural Science and Technology 3(1):129-145.

Febriani, Y., Riasari, H., Winingsih, W., Aulifa, D.L., Permatasari, A. 2017. The Potential Use of Red Ginger (Zingiber officinale Roscoe) Dregs as Analgesic. IJPST-SUPPI(1): 57-64.

Hasanah, S. 2013. Pemberdayaan Perempuan melalui Kegiatan Ekonomi Berkeadilan (Simpan Pinjam Syariah Perempuan).Sawwa 9 (1): 71-88.

Sadikim, R.Y., Sandhika, W., Saputro, I.D. 2018. Pengaruh Pemberian Ekstrak Jahe Merah (Zingiber officinale var. rubrum) terhadap Jumlah Sel Makrofag dan Pembuluh Darah pada Luka Bersih Mencit (Mus musculus) Jantan (Penelitian Eksperimental pada Hewan Coba). Berkala Ilmu Kesehatan Kulit dan Kelamin Vol 30 No. 2.

Sukandar, D., Hermanto, S., Amelia, E.R., Zaenudin, M. 2015. Aktivitas Antibakteri Ekstrak Biji Kapulaga (Amomum compactum Sol. Ex Maton). JKTI, Vol. 17, No. 2: 119-129.

Tjiptaningsih, W. 2017. Pemberdayaan Perempuan dalam Upaya Peningkatan Ekonomi Keluarga (Studi Kasus Pada Kelompok Usaha Perempuan di Desa Sindangkempeng Kecamatan Greged Kabupaten Cirebon). Reformasi, 1 (2): 2835 . 
Utami, N.W., Wahyudi, I.A., Larnani, S. 2012. Pengaruh Minyak Atsiri Kapulaga (Amomum cardamomum) Terhadap Kadar Metil Merkaptan yang Dihasilkan Bakteri Porphyromonas gingivalis (Kajian In Vitro). Maj Ked Gi, 19(1):17-20. 